\title{
A COMPARATIVE ANALYSIS OF FDI IN TURKEY AND THE CEECS: IS THERE ANY LINK BETWEEN FDI AND TRADE?
}

\author{
Levent Kosekahyaoglu \\ Süleyman Demirel Üniversitesi, İktisat Bölümü, 32260, Isparta, Turkey \\ E-mail: levent@iibf.sdu.edu.tr
}

Received 8 August 2006; accepted 8 November 2006

\begin{abstract}
This paper examines the structure of foreign direct investment (FDI) flows into Turkey and the Central and Eastern European Countries (CEECs) as well as the other new members of the European Union (EU). Our study has two main parts. Firstly, we investigate the key economic and political factors that have an impact on foreign investment, for example, the macroeconomic performance, the production cost and the size of domestic market. Secondly, we explore the relationship between FDI and trade flows for Turkey, the Czech Republic, Hungary and Poland using the Granger causality methodology.
\end{abstract}

Keywords: Foreign direct investment; Turkey; Granger causality method.

\section{Introduction}

Recently FDI has been increasingly considered as an important incentive to the industrial growth and international competitiveness for developing countries. Actually, several studies show that 'FDI triggers technology spillovers, assists human capital formation, contributes to international trade integration, helps create a more competitive business environment and enhances enterprise development.' ${ }^{1}$

In order to reap these benefits, attracting FDI has become a fierce competition among developing countries in last couple of decades. To be more competitive in this race, countries started to re-structure their political and economic policies by privatizing their public sector establishments and adopting incentive regimes through Investment Promotion Agencies. ${ }^{2}$

Multinational companies (MNCs) consider various political and economic factors in the process of deciding where to invest. First of all, foreign investors prefer countries that have well-functioning market economy and demand minimum bureaucratic obstacles. They compare countries on the basis of their respective pocket list for investment, which includes various information from political and economic stability to taxes, incentives, investment location, logistic costs, personnel costs, presence of skilled labour, costs and condition of infrastructure for transportation, telecommunication and energy.

Obviously, a country may not be good enough in all of the above mentioned factors, it may be very good in one but below average in others. However, it is the combination of all factors that shapes the final decision of foreign investors. Turkey has always attracted very low inflows of FDI relative to other comparable countries. Several reasons for this low performance can be listed as structural barriers, heavy bureaucratic requirements, macroeconomic instability, corruption, political instability and so on.

Competition between Turkey and the neighboring countries have gained particular significance, following the entry of countries in the Central and Eastern Europe into the market after the 1990s. FDI have increased substantially in the 1990s and developing countries classified as Turkey's competitors received substantial shares of this growth. However, Turkey 
could not sustain the favorable position it reached in the early 1990's and lingered in attracting FDI.

Most CEECs joined the European Union EU in May 2004 and they experienced a notable success at attracting FDI since they started membership negotiations with the EU in 1998. Meanwhile, the EU declared at the Brussels Summit in December 2004 that Turkey fulfilled the Copenhagen criteria so that it would start membership talks with the EU in October 2005. Consequently, a comparative study of FDI in Turkey and the new members of the EU has become even more appealing. Main motivation of this work is to carry out such analysis by evaluating the FDI performance of Turkey and CEECs.

The remainder of the paper is structured as follows. Section 2 summarizes Turkey's trade liberalization experience in the 1980s and examines the historical and the legal framework of FDI in Turkey. This section also presents FDI performance of Turkey between 1970 and 2003. Comparison of foreign investment in Turkey and the CEECs is given in Section 3. Section 4 specifies an empirical model for a causality analysis of the relationship between FDI and trade flows in Turkey and the former "Visegrad" countries (i.e. Poland, Hungary and the Czech Republic). Section 5 summarizes the main results and gives some suggestions for future work.

\section{Trade Liberalization and FDI Performance of Turkey}

\subsection{Trade Liberalization in Turkey}

During the 1929-1980 era, Turkish development strategies have been dominated by import-substitution with two short periods of relaxed trade controls in 195053 and 1970-73 (Utkulu and Ozdemir, 2003). A radical change in Turkey's export policy began in $1980^{3}$, necessitated by a poor economic performance in the 1970s. Although trade liberalization attempts in Turkey started at the beginning of 1950s, and continued in 1958 and 1970, these attempts were generally unsuccessful as they were only short-term solutions to balance-of-payments and foreign exchange problems (Baysan and Blitzer, 1991). What differed in 1980 the government's statement that, in addition to the usual stabilization measures, it intended to liberalize the whole economy more generally. ${ }^{4}$ There were significant alterations in Turkey's trade and payments regime and the overcome of these changes are given in Table 1 below.

Table 1 shows trend of some key foreign trade indicators over the period between 1970 and 2003. It is clear from Table 1 that there was a structural change in Turkey's foreign trade in terms of both volume and commodity composition of trade flows. We can draw four fundamental conclusions from Table 1:

a) There was a significant boost in Turkey's exports after the 1980s indicated by 16-fold increase in 24 years between 1980 and 2003. ${ }^{5}$

b) Imports had experienced even larger increase particularly in the 1990 s resulting in a big trade deficit over 20 Billion $\$$ in $2003 .{ }^{6}$

c) As a result of substantial increases in both exports and imports, Turkey's openness rate, defined as (exports + imports / GDP), went up from 15,8 in 1980 to 48.7 in 2003 . This increase in openness rate indicates that Turkey has become more vulnerable to external shocks after the 1980s.

d) While manufactured goods constituted only 36 per cent of total exports in 1980 their share rose to over 93 per cent in 2003. Therefore, it appears that there has been a considerable change in commodity composition of Turkey's exports after implementation of the 1980 program.

Table 1. Key Foreign Trade Indicators of Turkey, 1970-2003 (Billion \$)

\begin{tabular}{|c|c|c|c|c|c|c|c|c|c|c|}
\hline & 1970 & 1975 & 1980 & 1985 & 1990 & 1995 & 2000 & 2001 & 2002 & 2003 \\
\hline Exports & 588 & 1,401 & 2,910 & 7,958 & 12,959 & 21,636 & 27,774 & 31,334 & 35,757 & 47.253 \\
\hline Imports & 947 & 4,738 & 7,909 & 11,343 & 22,302 & 35,707 & 54,502 & 41,399 & 51,203 & 69.340 \\
\hline \multicolumn{11}{|l|}{ Trade } \\
\hline Volume & 1,536 & 6,139 & 10,819 & 19,301 & 35,261 & 57,343 & 82,277 & 72,733 & 86,961 & 116.593 \\
\hline Trade Deficit & -359 & $-3,337$ & $-4,999$ & $-3,385$ & $-9,342$ & $-14,071$ & $-26,728$ & $-10,065$ & $-15,445$ & -22.087 \\
\hline $\mathrm{Ex} / \operatorname{Im} \quad(\%)$ & 62,0 & 29,5 & 36,7 & 70,1 & 58,1 & 60,5 & 50,9 & 75,6 & 69,8 & 68,1 \\
\hline Ex/GDP ( \%) & 3,0 & 2,9 & 4,2 & 11,8 & 8,5 & 12,5 & 13,8 & 21,1 & 19,7 & 19,7 \\
\hline Im/GDP ( \%) & 4,9 & 9,9 & 11,5 & 16,9 & 14,6 & 20,7 & 27,1 & 27,9 & 28,3 & 28,9 \\
\hline Openness & 8,0 & 12,9 & 15,8 & 28,8 & 23,1 & 33,3 & 41,0 & 49,0 & 48,0 & 48,7 \\
\hline $\begin{array}{l}\text { Share of Man. } \\
\text { Exports ( } \%)\end{array}$ & 18,4 & N.A. & 36,0 & 75,3 & 79,0 & 88,2 & 91,2 & 91,5 & 93,1 & 93,4 \\
\hline
\end{tabular}

Source: State Planning Organization of Turkey, Undersecretariat of Foreign Trade. $\quad$ * (Exports + Imports) / GDP. 
Although there is a consensus on the success of the Turkish experience in the post- 1980 period, the driving forces behind it have remained a matter of debate. Some studies have stressed Turkey's liberal provision of export incentives. Others have concentrated on the macroeconomic and import liberalisation policies that caused Turkey's aggressive nominal exchange rate policy to result in sustained real depreciation (see, e.g., Anand et al., 1990). However, Celasun and Rodrik (1989) suggest that at most $30 \%$ of the increase in exports during the 1980 s can be attributed to real depreciation, and find little empirical support for any effect of export incentives.

In sum, it seems that there have been major structural changes in Turkish economy over the liberalization period after the $1980 \mathrm{~s}$. The structural transformation in Turkey has particularly been an outcome of steady growth of exports and even further increase in imports that resulted in both escalating trade deficit and openness rate. Although the rise in trade deficit and openness rate prepared the conditions for financial crisis in 1994 and 2001, the shift in Turkey's exports from labour-intensive primary goods to capitalintensive manufactured goods contributed significantly to the competitiveness of Turkish industry. As Narula and Wakelin (1998) and Alguacil et al. (2002) argue, there may be a link between FDI and composition of exports. Therefore, increasing trend of FDI in Turkey can be considered an important factor in explaining the shift in exports of manufactured goods particularly after the 1990 s.

\subsection{Performance of FDI in Turkey}

\subsubsection{Historical and Legal Background of FDI in Turkey}

Beginning in the early 1950 s, Turkish policy makers, aware of the contribution of foreign capital to economic development, have taken serious steps to encourage the inflow of foreign capital. However, there was still a very skeptical approach on foreign capital in Turkey especially in the 1960s and 1970s as a result of some historical developments dating back to Ottoman Empire. There were many debates about the issue in the press and in public and most of the studies during this period had a negative manner towards foreign investment. Although the Law No. 6224 on the Encouragement of Foreign Capital was designed as a liberal law in 1954, it was implemented accurately to promote foreign investment due the skeptical approach. During this period a very small amount of FDI entered into Turkey and its share was not important in the Turkish economy.
However, developments in foreign investments accelerated along with the changes in the economic and social structure in Turkey after the 1980 s. The deregulation of interest rates, establishment of organized financial markets for money, foreign exchange stocks and securities, liberalization of capital movements and reforms in the banking sector are just same of the major economic policy changes while one of the major policy decisions was the adoption of liberal and flexible foreign investment practices. As a result of the changes in the foreign investment legislation, the investment climate was made more efficient and suitable for potential investors.

The improvement of foreign investment environment in Turkey was a priority item particularly in the 2000s but it was interrupted by the political instability and financial crisis. The new Law No. 4875 on foreign direct investments, amending a number of other laws related to the rights of foreign investors and some arrangements downsizing the bureaucratic procedures related with company formation, have finally been passed by the Parliament and it came into force as of 17 June 2003. ${ }^{7}$ Initiatives for further betterment continued in the forms of works for the establishment of an Investment Promotion Agency and reshaping incentive mechanisms.

Some of the important features of the new law are a broader definition of investors to include foreign nationals, Turkish nationals resident abroad, foreign legal entities and international organizations; freedom to invest; internationally accepted FDI definition; national treatment; guarantee to transfer proceeds; key expatriate personnel; protection against expropriation; access to real estate and international dispute settlement.

\subsubsection{FDI Performance of Turkey}

\subsubsection{Trend of FDI Flows and Number of Foreign Equity Companies}

Aim of this section is to evaluate Turkey's FDI performance over the pre and post liberalization periods. Figure 1 illustrates annual FDI inflows to Turkey between 1970 and 2003. It is clear from the figure that annual FDI inflow was very low in the 1970s and the average annual inflow of FDI between 1970 and 1980 was only $\$ 50$ million. ${ }^{8}$ As Balasubramanyam (1996) shows, this was far less than other comparable countries, and FDI did not increase significantly for most of the 1980s. It was only with a shift in Turkey from a protectionist trade regime to export-oriented economic liberalization in the mid-1980s that FDI increased significantly. 


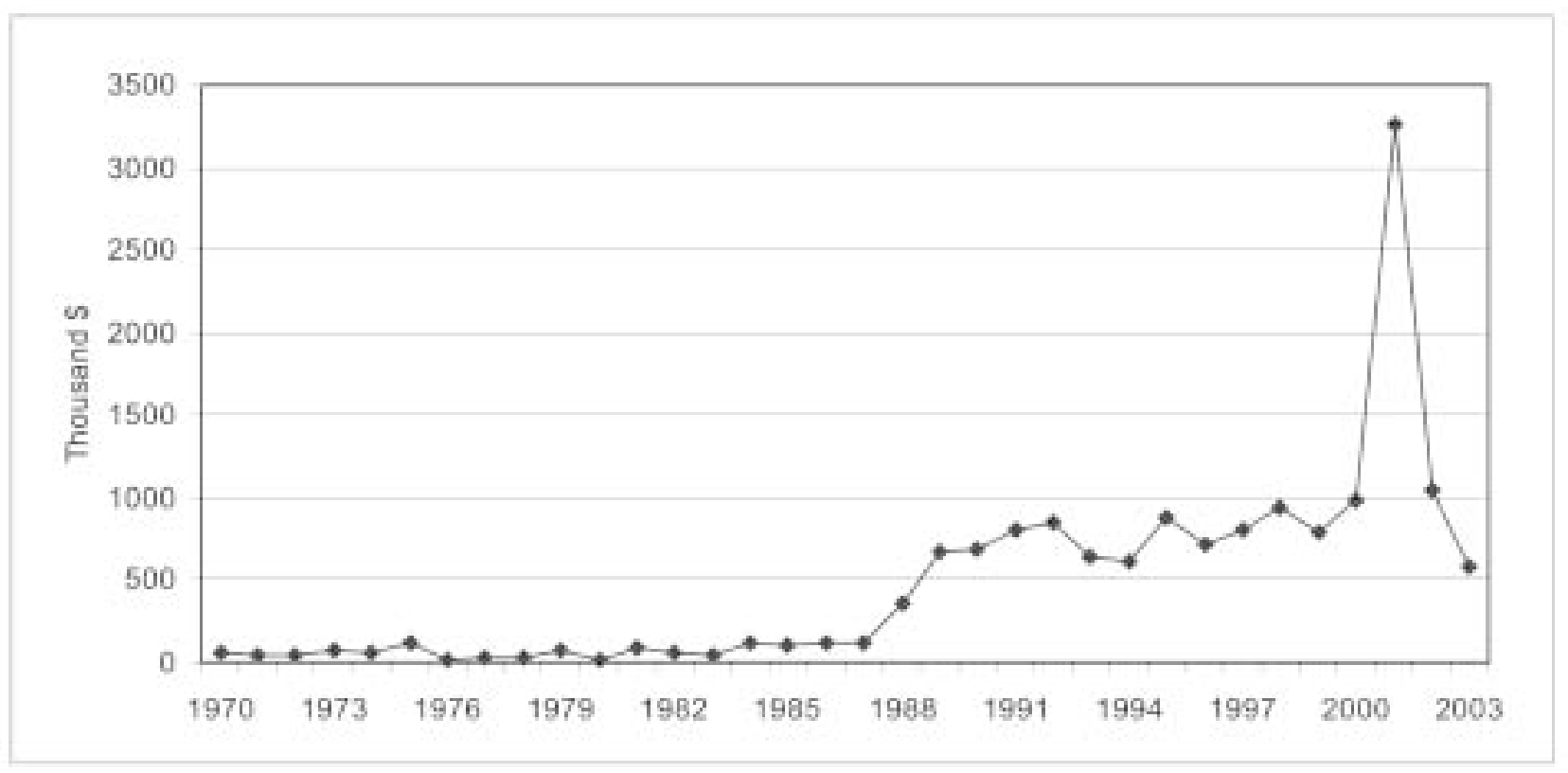

Source: UNCTAD, World Investment Report, 2004.

Fig 1. Trend of FDI inflows in Turkey between 1970-2003

Fig 1 also indicates that annual FDI inflows in Turkey reached $\$ 500$ million and $\$ 1$ billion in the 1990s and 2000s, respectively. The year 2001 was an exception as Turkey's FDI inflow reached $\$ 3.2$ billion, but more than half of this was accounted for by Telecom Italia and HSBC acquisitions.

However, if we consider the number of FDI companies in Turkey we see a different picture. It is clear from Fig 2 that the number of foreign equity companies in Turkey has increased continuously since the mid-1980s. Actually, while the number of new companies with foreign equity was around 300 per year between the mid-1980s and mid-1990s, this has increased to almost 450 per year after 1995 .

In sum, though FDI flows show FDI in Turkey to be particularly static over the first decade of the liber-

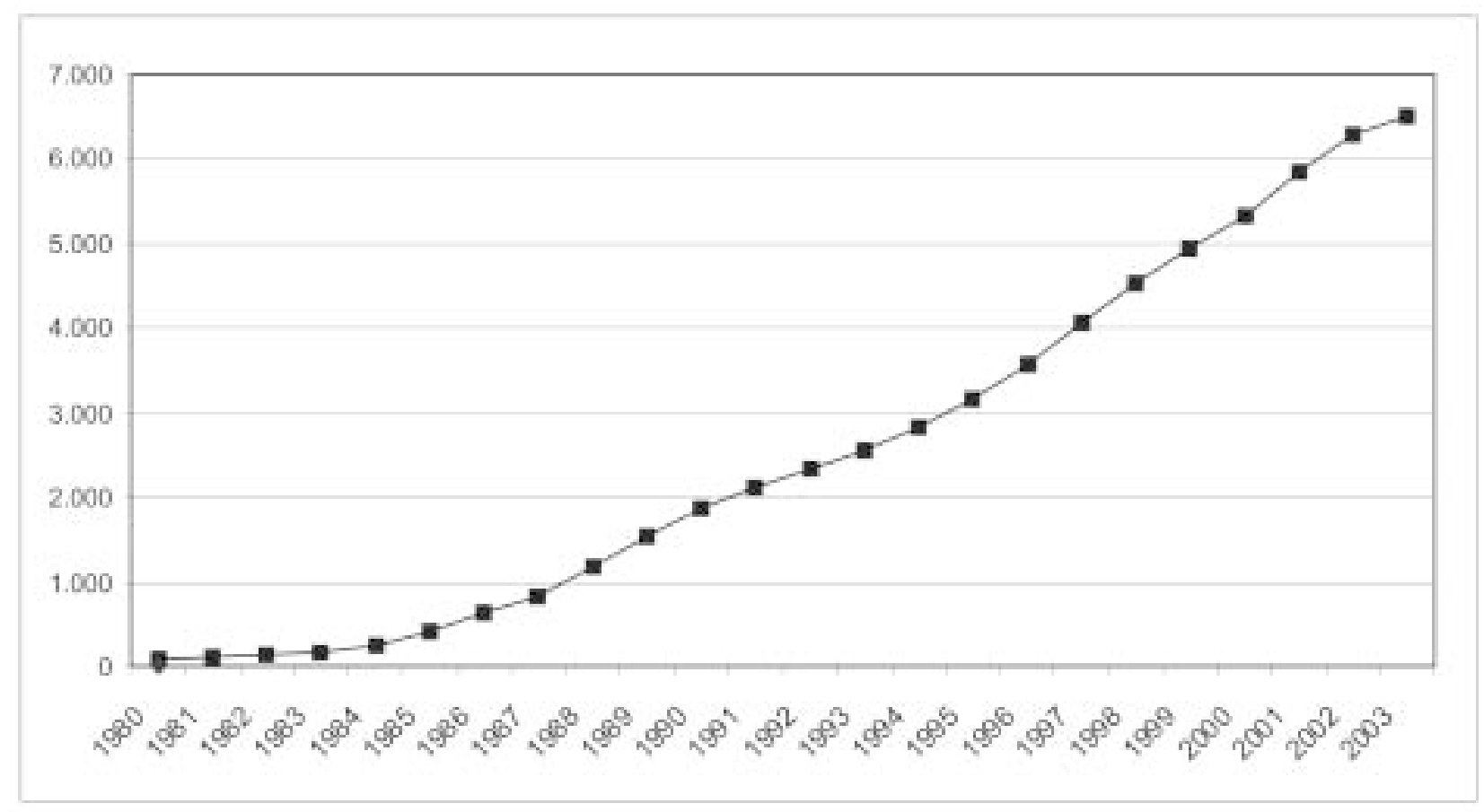

Source: Treasury of Turkey.

Fig 2. Total number of foreign capital firms in Turkey, 1980-2003 
alization period until the 1990s, when we look at the number of companies with foreign capital we realise that the total number of foreign equity companies has noticeably increased after the mid-1980s reaching from only 400 in 1985 to 5,300 and 6.500 in 2000 and 2003, respectively.

\subsubsection{Breakdown of FDI by sector and country}

Table 2 shows the breakdown of FDI in Turkey by sectors and sub-sectors over the period between 1980 and 2003. It is clear from Table 3 that manufacturing and services dominate FDI in Turkey and there has not been much change in their share of total FDI over time. Table 3 shows the contribution of foreign capital in the total capital of the foreign equity ventures for some selected sectors giving us an exact indicator of the role of joint ventures in FDI in Turkey.

Table 3 also indicates that among the 6,511 foreign equity ventures, foreign capital accounted for about $60 \%$ of the total. In other terms, FDI appears to leverage an additional $40 \%$ of domestic investment. This shows the degree of joint ventures between foreign owned and Turkish firms and the spillover effect of FDI to Turkey's economy. Tatoglu and Glaister (2000) argue that up to half of all foreign equity ventures in Turkey have been joint ventures.
Loewendahl and Ertugal Loewendahl (2001) monitor FDI projects in Turkey in the first half of 2000 using media searches and report that the most important sector for projects is the information technology and telecommunications (IT\&T) sector, which attracted about one-third of the projects they monitored. They argue that their findings reflect the rapid growth of new economy activities in Turkey, in particular mobile telecommunications, e-business, Internet, and banking. ${ }^{9}$ The next most important sectors in their study were automotive and electronics.

As for the distribution of FDI according to home countries, we can see from Table 4 that European countries dominate FDI in Turkey. France, Netherlands and Germany appear to be the three major investor countries in Turkey in terms of approved investment. ${ }^{10}$ Total approved FDI by France and Netherlands together amounted to almost $\$ 11$ billion between 1980 and 2002 accounting for about \% 40 of total approved capital.

In sum, considering FDI capital flows alone it can be argued that Turkey has under performed and was not successful in attracting FDI over time. Several economic, legal and political factors have played a major role in this poor FDI performance in Turkey.

Table 2. Sectoral Breakdown of Authorized FDI in Turkey, 1980-2003, Million \$

\begin{tabular}{|c|c|c|c|c|c|c|c|c|}
\hline & MANUFACTURING & $\%$ & AGRICULTURE & $\%$ & MINING & $\%$ & SERVICES & $\%$ \\
\hline 1980 & 88,76 & 92 & - & 0 & - & 0 & 8,24 & 8 \\
\hline 1981 & 246,54 & 73 & 0,86 & 0 & 0,98 & 0 & 89,13 & 26 \\
\hline 1982 & 98,54 & 59 & 1,06 & 1 & 1,97 & 1 & 65,43 & 39 \\
\hline 1983 & 88,93 & 87 & 0,03 & 0 & 0,02 & 0 & 13,76 & 13 \\
\hline 1984 & 185,92 & 69 & 5,93 & 2 & 0,25 & 0 & 79,26 & 29 \\
\hline 1985 & 142,89 & 61 & 6,37 & 3 & 4,26 & 2 & 80,97 & 35 \\
\hline 1986 & 193,47 & 53 & 16,86 & 5 & 0,86 & 0 & 152,81 & 42 \\
\hline 1987 & 293,91 & 45 & 13,00 & 2 & 1,25 & 0 & 347,08 & 53 \\
\hline 1988 & 490,68 & 60 & 27,35 & 3 & 5,62 & 1 & 296,87 & 36 \\
\hline 1989 & 950,13 & 63 & 9,36 & 1 & 11,69 & 1 & 540,59 & 36 \\
\hline 1990 & $1.214,06$ & 65 & 65,56 & 4 & 47,19 & 3 & 534,49 & 29 \\
\hline 1991 & $1.095,48$ & 56 & 22,41 & 1 & 39,82 & 2 & 809,55 & 41 \\
\hline 1992 & $1.274,28$ & 70 & 33,59 & 2 & 18,96 & 1 & 493,13 & 27 \\
\hline 1993 & $1.568,59$ & 76 & 21,05 & 1 & 11,37 & 1 & 462,38 & 22 \\
\hline 1994 & $1.107,29$ & 75 & 28,27 & 2 & 6,20 & 0 & 335,85 & 23 \\
\hline 1995 & $1.996,48$ & 68 & 31,74 & 1 & 60,62 & 2 & 849,48 & 29 \\
\hline 1996 & 640,59 & 17 & 64,10 & 2 & 8,54 & 0 & $3.122,74$ & 81 \\
\hline 1997 & 871,81 & 52 & 12,22 & 1 & 26,70 & 2 & 767,48 & 46 \\
\hline 1998 & $1.017,29$ & 62 & 5,75 & 0 & 13,73 & 1 & 609,67 & 37 \\
\hline 1999 & $1.123,22$ & 66 & 16,19 & 1 & 6,76 & 0 & 553,40 & 33 \\
\hline 2000 & $1.105,49$ & 32 & 59,74 & 2 & 5,01 & 0 & $2.307,18$ & 66 \\
\hline 2001 & $1.244,59$ & 46 & 134,38 & 5 & 29,11 & 1 & $1.317,20$ & 48 \\
\hline 2002 & 892,01 & 40 & 32,82 & 1 & 17,29 & 1 & $1.300,81$ & 58 \\
\hline 2003 & 710,65 & 59 & 7,73 & 1 & 124,18 & 10 & 365,43 & 30 \\
\hline Total & $18.641,60$ & 53 & 616,37 & 1,80 & 442,38 & 1,30 & $15.502,93$ & 44 \\
\hline
\end{tabular}

Source: Treasury of Turkey. 
Table 3. Sectoral distribution of foreign capital companies in Turkey*

\begin{tabular}{|c|c|c|c|}
\hline Sector & Number of Firms & $\%$ in total foreign capital & $\begin{array}{l}\% \text { of foreign capital in total } \\
\text { capital }\end{array}$ \\
\hline Total Agriculture & 151 & 3,63 & 94,65 \\
\hline Total Mining & 101 & 0.49 & 80,08 \\
\hline $\begin{array}{l}\text { Total Manufacturing, } \\
\text { of which }\end{array}$ & 1.667 & 41,52 & 58,82 \\
\hline Food Manufacturing & 168 & 6,09 & 67,17 \\
\hline Beverage & 5 & 0.19 & 93,38 \\
\hline Tobacco & 14 & 1,85 & 92,63 \\
\hline Textiles & 67 & 0,21 & 40,11 \\
\hline Garments & 224 & 1,63 & 50,08 \\
\hline Plastics & 82 & 0,88 & 70,51 \\
\hline Iron and steel & 20 & 1,42 & 18,29 \\
\hline Electrical machinery & 95 & 2,42 & 82,00 \\
\hline Electronics & 120 & 1,82 & 56,94 \\
\hline Automotive & 37 & 5,13 & 62,82 \\
\hline Automotive side industries & 130 & 4,01 & 59,33 \\
\hline Total Energy & 51 & 4,79 & 93,56 \\
\hline $\begin{array}{l}\text { Total Services, } \\
\text { of which }\end{array}$ & 4.541 & 49,57 & 58,82 \\
\hline Trade & 2.470 & 6,51 & 75,51 \\
\hline Hotels & 360 & 4,02 & 82,21 \\
\hline Construction & 200 & 0,60 & 61,46 \\
\hline Social Services & 269 & 4,98 & 79,79 \\
\hline Communication & 45 & 9,35 & 46,64 \\
\hline Investment Finance & 70 & 5,31 & 41,72 \\
\hline Banking and other Financial Services & 37 & 10,56 & 54,11 \\
\hline TOTAL & 6.511 & 100,00 & 60,81 \\
\hline
\end{tabular}

Source: Treasury of Turkey. $\quad{ }^{*}$ As of June 2003.

Table 4. Breakdown of Authorised FDI According to Home Countries in Turkey, million \$

\begin{tabular}{lcccccccccc}
\hline Country & $\mathbf{1 9 8 0}-$ & $\mathbf{1 9 9 1 -}$ & $\mathbf{1 9 9 6}$ & $\mathbf{1 9 9 7}$ & $\mathbf{1 9 9 8}$ & $\mathbf{1 9 9 9}$ & $\mathbf{2 0 0 0}$ & $\mathbf{2 0 0 1}$ & $\mathbf{2 0 0 2}$ & TOTAL \\
\hline & $1.045,6$ & 1557,4 & $2.370,3$ & 103,9 & 135,5 & 146,7 & 33,7 & 137,7 & 134,0 & $5.665,0$ \\
France & & & & & & & & & \\
Netherlands & 322,4 & 1485,9 & 338,6 & 206,3 & 352,0 & 234,5 & $1.381,3$ & 635,4 & 379,2 & $5.336,0$ \\
Germany & 696,4 & 1159,8 & 226,4 & 281,5 & 329,8 & 407,3 & 636,8 & 319,3 & 271,9 & $4.329,4$ \\
US & 770,5 & 1296,4 & 179,4 & 174,4 & 297,2 & 292,5 & 291,3 & 316,0 & 310,7 & $3.928,7$ \\
UK & 877,4 & 519,4 & 164,8 & 122,2 & 44,43 & 88,4 & 98,1 & 506,5 & 247,6 & $2.669,1$ \\
Switzerland & 799,6 & 830,7 & 156,8 & 50,2 & 101,5 & 50,8 & 35,2 & 86,1 & 149,3 & $2.260,6$ \\
Italy & 214,0 & 982,1 & 43,2 & 124,5 & 128,6 & 95,2 & 17,8 & 33,6 & 243,5 & $1.882,8$ \\
Japan & 363,3 & 738,0 & 21,1 & 126,6 & 17,5 & 13,8 & 150,7 & 258,6 & 128,7 & $1.818,6$ \\
Others & 582,1 & 265,1 & 74,8 & 297,6 & 40,4 & 198,1 & 62,1 & 71,3 & 82,7 & $1.674,6$ \\
\hline
\end{tabular}

Source: Treasury of Turkey.

According to Turkish Foreign Investors Association (FIS), the key elements behind Turkey's ability to attract FDI are: the longstanding political instability which also resulted in the price instability, the heavy bureaucratic obstacles to company establishment, the difficulties in obtaining short-term working permits, the high level of taxes, the complexity of custom transaction, tax and subsidy system, the problems related to intellectual property rights and finally, the lack of agencies for investment promotion ${ }^{11}$.
Once we take into account the number of foreign equity companies, joint ventures, and new forms of investment, it becomes clear that foreign companies are making an important and growing contribution to the competitiveness of the Turkish economy. According to OECD (1999), foreign affiliates account for about $20 \%$ of total research and development (R\&D) expenditure in Turkey and for over $70 \%$ of patent applications to the European Patent Office which is higher than any other country in the OECD except Iceland. 


\section{Comparison of Turkey with 10 new members of the $\mathrm{EU}$}

\subsection{General Remarks}

Following decision of the EU at the Brussels Summit in December 2004 on starting accession negotiations with Turkey at the beginning of October 2005, a comparative analysis of FDI attractiveness of Turkey and the CEECs ${ }^{12}$ together with the other 5 new members of the EU has become even more appealing. ${ }^{13}$ As Bevan and Estrin (2004) suggest announcements on EU proposals have an important impact on FDI for the potential member countries. ${ }^{14}$ Considering that fact, the aim of this section is to compare the FDI attractiveness of Turkey with that of the 10 new members of EU as well as the two potential members namely, Bulgaria and Romania. We shall analyze Turkey and the other countries in terms of inward and outward FDI flows as well as FDI stock in the following sections.

Although there is a vast literature on the structure and the determinants of FDI in the CEECs (see for example, Carstensen and Toubal (2004); Bevan and Estrin (2004); Buch et al. (2003); Alessandrini (2000); Altomonte (2000); and Resmini (2000 and 2002), the number of comparative studies covering Turkey and the 10 new EU members is very limited. ${ }^{15}$ Altomonte and Guagliano (2003), for example, construct a panel of more than 3500 European multinationals that have invested in Central and Eastern Europe and the Mediterranean countries including Turkey over the 1990-
1997 period. They find that Central and Eastern Europe displays a greater potential in the attraction of FDI flows when compared to the Mediterranean region.

\subsection{Comparison of inward and outward FDI flows and FDI stock in Turkey and the others}

Trends of FDI inflows, FDI stock and FDI outflows in Turkey and the other countries are given in Tables 5, 6 and 7, respectively. Considering FDI inflows first, we can see from Table 5 that the main three competitors of Turkey are the Czech Republic, Hungary and Poland and that the gap between Turkey and its competitors has grown particularly after the start of the three competitor countries' accession talks with EU in 1998. ${ }^{16}$ Carstensen and Toubal (2004) argue that Hungary and the Czech Republic followed a policy of fast privatization and exhibited a sound political and legal system, therefore, their FDI performance was exceptionally well.

It appears that the South Eastern European countries, such as Bulgaria and Romania, lag far behind the Central European countries, for instance the Czech Republic, Hungary and Poland, in attracting foreign capital. Carstensen and Toubal (2004) argue that this difference cannot be entirely explained by traditional FDI determinants because transition-specific factors play a key role in the investment decision of multinational company as they mirror the actual condition of the transition process, the overall policy stance, or even future prospects.

Table 5. Comparison of Turkey with Romania, Bulgaria and the 10 new members of the EU in terms of FDI inflows between 1992 and 2003, million \$

\begin{tabular}{|c|c|c|c|c|c|c|c|}
\hline & $1992-1997^{1}$ & 1998 & 1999 & 2000 & 2001 & 2002 & 2003 \\
\hline Cyprus & 150 & 264 & 685 & 804 & 652 & 614 & 830 \\
\hline Czech R. & 1304 & 3700 & 6310 & 4984 & 5639 & 8483 & 2583 \\
\hline Estonia & 180 & 581 & 305 & 387 & 542 & 284 & 891 \\
\hline Hungary & 2924 & 3828 & 3312 & 2764 & 3936 & 2845 & 2470 \\
\hline Latvia & 229 & 357 & 347 & 411 & 163 & 384 & 360 \\
\hline Lithuania & 108 & 926 & 486 & 379 & 446 & 732 & 179 \\
\hline Malta & 126 & 267 & 822 & 622 & 281 & $-428^{2}$ & 380 \\
\hline Poland & 2889 & 6365 & 7270 & 9341 & 5713 & 4131 & 4225 \\
\hline Slovakia & 235 & 707 & 428 & 1925 & 1584 & 4123 & 571 \\
\hline Slovenia & 166 & 218 & 106 & 137 & 369 & 1606 & 181 \\
\hline Romania & 402 & 2031 & 1041 & 1037 & 1157 & 1144 & 1566 \\
\hline Bulgaria & 149 & 537 & 819 & 1002 & 813 & 905 & 1419 \\
\hline Turkey & 750 & 940 & 783 & 982 & 3,266 & 1,038 & 575 \\
\hline
\end{tabular}

Source: UNCTAD World Investment Report 2004. ${ }^{1}$ Annual average. ${ }^{2}$ FDI flows are a source, not a use, of corporate finance, which makes them different from fixed investment flows conceptually. FDI flows are the sum of equity, reinvested earnings and loans remitted from the parent firm and related firms abroad to an affiliate in which it controls an ownership share above a certain threshold. Therefore, an increase (decrease) in FDI stock indicates positive (negative) net FDI flows. 
It can be also concluded from Table 5 that rapid increase of FDI inflows has slowed down noticeably in the Czech Republic, Lithuania, Slovakia, Slovenia and Turkey in 2003. However, Turkish Foreign Investors Association (FIS) expects FDI inflows in Turkey to reach $\$ 2,5$ billion at the end of 2004. Their prediction for FDI inflows excluding privatization in 2005 is $\$ 4$ billion.

Development of FDI stock in Turkey and the others over the period between 1980 and 2003 is given in Table 6. It appears that the Czech Republic, Hungary, Poland and Turkey are rival countries not only in terms of FDI inflows but also FDI stock. Consistent with the increase in FDI inflows, most countries (e.g. Romania, the Czech Republic, Hungary and particularly Poland) have recently experienced substantial increases in their FDI stock after the year 2000.
When we examine FDI outflows, we can see from Table 7 that the overall extent of FDI outflows from the countries we consider has been under $\$ 1$ billion by far with the only exception of Hungary in 2003. The low level of FDI outflow may simply be a result of the deficient national capital formation in the CEECs that recently started to implement liberal economic policies only after the 1990 s. Relatively higher level of FDI outflows from Turkey and Cyprus is consistent with that explanation.

\subsection{Comparison of Macroeconomic Performance in Turkey and the Others}

In order to shed some light on the sources of differences in FDI performance presented in section 3, this section aims to examine the factors that influence the

Table 6. Comparison of Turkey with Romania, Bulgaria and the 10 new members of the EU in terms of FDI stock* between 1980 and 2003, million \$

\begin{tabular}{lccccccc}
\hline & $\mathbf{1 9 8 0}$ & 1985 & $\mathbf{1 9 9 0}$ & $\mathbf{1 9 9 5}$ & $\mathbf{2 0 0 0}$ & $\mathbf{2 0 0 2}$ & $\mathbf{2 0 0 3}$ \\
\hline Cyprus & 173 & 502 & 859 & 1.293 & 3.591 & 4.856 & 5.686 \\
Czech R. & N.A. & N.A. & 1.363 & 7.350 & 21.644 & 38.450 & 41.033 \\
Estonia & N.A. & N.A. & N.A. & 688 & 2.645 & 4.226 & 6.511 \\
Hungary & N.A. & 49 & 569 & 11.304 & 22.870 & 35.890 & 42.915 \\
Latvia & N.A. & N.A. & N.A. & 615 & 2.084 & 2.751 & 3.320 \\
Lithuania & N.A. & N.A. & N.A. & 352 & 2.334 & 3.981 & 4.960 \\
Malta & 156 & 286 & 465 & 562 & 2.374 & 2.110 & 2.490 \\
Poland & N.A. & N.A. & 109 & 7.843 & 35.227 & 47.900 & 52.125 \\
Slovakia & N.A. & N.A. & 81 & 810 & 3.738 & 7.800 & 10.248 \\
Slovenia & N.A. & N.A. & 594 & 1.763 & 2.894 & 4.109 & 4.290 \\
Romania & N.A. & N.A. & N.A. & 821 & 6.480 & 8.873 & 12.693 \\
Bulgaria & N.A. & N.A. & 112 & 445 & 2.257 & 3.662 & 5.082 \\
Turkey & 8. 845 & 9.253 & 11.194 & 14.977 & 19.209 & 17.621 & 18.196 \\
\hline
\end{tabular}

Source: UNCTAD World Investment Report 2004. ${ }^{*}$ FDI stock $=$ FDI equity + FDI reinvested earnings + FDI loans $=$ fixed assets + nonfixed assets - (non-FDI equity + non-FDI loans).

Table 7. Comparison of Turkey with Romania, Bulgaria and the 10 new members of the EU in terms of FDI outflows between 1992 and 2003, million \$

\begin{tabular}{|c|c|c|c|c|c|c|c|}
\hline & $1992-1997^{1}$ & 1998 & 1999 & 2000 & 2001 & 2002 & 2003 \\
\hline Cyprus & 24 & 69 & 146 & 202 & 218 & 299 & 345 \\
\hline Czech R. & 74 & 125 & 90 & 43 & 165 & 206 & 232 \\
\hline Estonia & 32 & 6 & 83 & 63 & 200 & 132 & 148 \\
\hline Hungary & 96 & 319 & 250 & 620 & 368 & 275 & 1.581 \\
\hline Latvia & -21 & 54 & 17 & 10 & 12 & 8 & 32 \\
\hline Lithuania & 9 & 4 & 9 & 4 & 7 & 18 & 37 \\
\hline Malta & 6 & 15 & 45 & 26 & 24 & -4 & 24 \\
\hline Poland & 33 & 316 & 31 & 17 & -90 & 230 & 386 \\
\hline Slovakia & 39 & 147 & -371 & 21 & 35 & 5 & 22 \\
\hline Slovenia & 2 & -5 & 48 & 66 & 144 & 93 & 304 \\
\hline Romania & N.A. & -9 & 16 & -11 & -17 & 16 & 56 \\
\hline Bulgaria & -9 & N.A. & 17 & 3 & 10 & 28 & 22 \\
\hline Turkey & 100 & 367 & 645 & 870 & 497 & 175 & 499 \\
\hline
\end{tabular}

Source: UNCTAD World Investment Report 2004. ${ }^{1}$ Annual average. 
macroeconomic performance (GDP growth, GDP per capita and price stability), the labour cost (wages) and the size of home market (total population) of the countries we consider. We also present an overall evaluation of the FDI attractiveness of Turkey and the other countries.

To study macroeconomic performance, we first focus on the current GDP ${ }^{17}$, the GDP growth and the GDP per capita. In terms of the current GDP, Poland and Turkey appear to be the countries with the highest current GDP over $\$ 200$ billion (See Table 8) ${ }^{18}$. They are followed by the Czech Republic, Hungary and Romania which have a current GDP under $\$ 100$ billion.

However, when we consider not the size but the growth of income, we see a different picture. Table 8 also shows that Latvia and Estonia have the highest average annual GDP growth over the 5 years between 1999 and 2003. Turkey also appears to be one of the fastest growing economies but, due to the earthquake in 1999 and the financial crisis of 2001, the trend of GDP growth in Turkey has been rather unstable.

Concerning the GDP per capita, it is clear from Table 8 that although Turkey and Poland have the biggest income, GDP per capita in these countries is rather lower than the others because of their relatively large population (see Table 9). Cyprus and Slovenia are the countries with the highest income per capita while Romania and Bulgaria are the ones with lowest income.

When we consider the price stability, which is also used as a proxy for political stability, we can see from Table 9 that almost all countries, excluding Romania and Turkey ${ }^{19}$, managed to keep their inflation rates under 10 per cent over time. Although this level of inflation is still relatively higher than the overall average of the EU, which is about 2.5 per cent, all countries in Table 9 appear to be successful at reducing their inflation rates in recent years.

Another important aspect of comparing the countries in our sample is the cost of production which may be an important factor in FDI decisions of foreign firms. Table 9 shows that Cyprus and Slovenia are the countries with the highest monthly wages above a thousand $\cdot$. Assessment of relation between the FDI inflows and the labour cost raises crucial issues in studies of determinants of FDI and theoretically a negative relation is expected between the two factors ${ }^{20}$. However, a comparison of the FDI inflows (see Table 5) and the labour cost (see Table 9) indicates that although some countries have a relatively low production cost (e.g. Romania and Bulgaria), they may still remain behind the others in attracting FDI inflows.

Total population is a frequently employed proxy for market size. Meyer (1998), Barell and Holland (2000); Holland and Pain (1998) find FDI to be significantly and positively influenced by the size of domestic market. However, Carstensen and Toubal (2004) argue that the effect of market size on FDI inflows in CEECs must be treated carefully because FDI inflows coincided with a period of recession up to 1995 , which has been associated with the transition to a market economy (Kornai 1994, 1995; Lavigne, 1999; Roland, 2000). Therefore, a perverse but spurious relationship between FDI and market size would result from using the actual output of the host country. Consistent

Table 8. Comparison of Turkey with Romania, Bulgaria and the 10 new members of the EU in terms of macroeconomic performance

\begin{tabular}{|c|c|c|c|c|c|c|c|c|c|c|c|c|c|c|c|}
\hline \multirow[t]{2}{*}{2003} & \multicolumn{5}{|c|}{$\begin{array}{c}\text { Current GDP } \\
\text { Billion US \$ }\end{array}$} & \multicolumn{5}{|c|}{$\begin{array}{l}\text { GDP Growth } \\
\text { Annual \% }\end{array}$} & \multicolumn{5}{|c|}{$\begin{array}{c}\text { Current GDP per capita } \\
\text { Thousand US \$ }\end{array}$} \\
\hline & 1999 & 2000 & 2001 & 2002 & 2003 & 1999 & 2000 & 2001 & 2002 & 2003 & 1999 & 2000 & 2001 & 2002 & 2003 \\
\hline Cyprus & 9,2 & 8,8 & 9,1 & 10,1 & 11,3 & 5 & 5 & 4 & 2 & 4 & 12,220 & 12,460 & 12,320 & N.A & N.A \\
\hline Czech R. & 54,9 & 51,4 & 57,1 & 69,5 & 85,4 & 0 & 3 & 3 & 2 & 3 & 5,120 & 5,250 & 5,260 & 5,490 & 6,740 \\
\hline Estonia & 5,1 & 5,1 & 5,6 & 6,5 & 8,3 & -1 & 7 & 6 & 6 & 5 & 3,540 & 3,790 & 3,930 & 4,190 & 4,960 \\
\hline Hungary & 48,0 & 46,6 & 51,8 & 64,9 & 82,8 & 4 & 5 & 4 & 4 & 3 & 4,480 & 4,660 & 4,780 & 5,240 & 6,330 \\
\hline Latvia & 6,6 & 7,1 & 7,6 & 8,4 & 9,6 & 3 & 7 & 8 & 6 & 7 & 2,570 & 2,940 & 3,260 & 3,490 & 4,070 \\
\hline Lithuania & 10,8 & 11,3 & 12,0 & 14,0 & 18,2 & -2 & 4 & 6 & 7 & 7 & 2,910 & 3,170 & 3,400 & 3,730 & 4,490 \\
\hline Malta & 3,6 & 3,5 & 3,6 & 3,8 & N.A & 4 & 6 & -1 & 2 & N.A & 9,270 & 9,300 & 9,280 & 9,260 & N.A \\
\hline Poland & 164,4 & 166,5 & 185,7 & 191,3 & 209,5 & 5 & 4 & 4 & 1 & 4 & 4,320 & 4,440 & 4,570 & 4,670 & 5,270 \\
\hline Slovakia & 20,3 & 20,2 & 20,8 & 24,1 & 31,8 & 1 & 2 & 4 & 4 & 4 & 3,900 & 3,860 & 3,830 & 4,050 & 4,920 \\
\hline Slovenia & 20,0 & 18,9 & 19,5 & 21,9 & 26,2 & 5 & 5 & 3 & 3 & 2 & 10,010 & 10,260 & 10,110 & 10,200 & 11,830 \\
\hline Romania & 35,5 & 37,0 & 40,1 & 45,7 & 60,3 & -1 & 1 & 5 & 4 & 8 & 1,580 & 1,680 & 1,720 & 1,920 & 2,310 \\
\hline Bulgaria & 12,9 & 12,6 & 13,5 & 15,5 & 19,8 & 2 & 5 & 4 & 5 & 4 & 1,450 & 1,590 & 1,680 & 1,790 & 2,130 \\
\hline Turkey & 183,8 & 199,2 & 145,2 & 183,8 & 237,9 & -5 & 7 & -7 & 8 & 6 & 2,800 & 2,980 & 2,420 & 2,510 & 2,790 \\
\hline
\end{tabular}

Source; World Bank (2004) World Development Indicators. 
Table 9. Comparison of Turkey with Romania, Bulgaria and the 10 new members of the EU in terms of inflation, wages and population

\begin{tabular}{|c|c|c|c|c|c|c|c|c|c|c|c|c|c|c|c|}
\hline \multirow[t]{2}{*}{ Country } & \multicolumn{5}{|c|}{$\begin{array}{c}\text { Inflation } \\
\text { GDP Deflator, Annual \% } \\
\end{array}$} & \multicolumn{5}{|c|}{$\begin{array}{c}\text { Monthly Wages* } \\
\text { Hundred } €\end{array}$} & \multicolumn{5}{|c|}{$\begin{array}{c}\text { Total Population } \\
\text { Million } \\
\end{array}$} \\
\hline & 1999 & 2000 & 2001 & 2002 & 2003 & 1998 & 1999 & 2000 & 2001 & 2002 & 1999 & 2000 & 2001 & 2002 & 2003 \\
\hline Cyprus & 2 & 4 & 3 & 3 & 4 & 1376.5 & 1410.8 & 1522.9 & 1573.6 & 1676.5 & 0,75 & 0,75 & 0,76 & 0,76 & 0,77 \\
\hline Czech R. & 3 & 1 & 6 & 3 & 3 & 469.7 & 491.2 & 550.0 & 614.1 & 724.1 & 10,2 & 10,2 & 10,2 & 10,2 & 10,2 \\
\hline Estonia & 4 & 7 & 5 & 4 & 3 & 357.4 & 375.9 & 418.7 & 465.5 & 517.4 & 1,3 & 1,3 & 1,3 & 1,3 & 1,3 \\
\hline Hungary & 8 & 10 & 9 & 9 & 8 & 481.1 & 510.9 & 559.1 & 621.4 & N.A & 10,0 & 10,0 & 10,1 & 10,1 & 10,1 \\
\hline Latvia & 5 & 5 & 3 & 2 & -1 & 268.4 & 295.7 & 341.9 & 350.5 & 359.6 & 2,3 & 2,3 & 2,3 & 2,3 & 2,3 \\
\hline Lithuania & -1 & 1 & -0 & -0 & 1 & 300.6 & 336.7 & 394.5 & N.A & N.A & 3,5 & 3,5 & 3,4 & 3,4 & 3,4 \\
\hline Malta & 3 & 1 & 6 & 1 & N.A & N.A & N.A & N.A & N.A & N.A & 0,38 & 0,39 & 0,39 & 0,39 & 0,39 \\
\hline Poland & 6 & 7 & 1 & 2 & 1 & 552.9 & 585.3 & 657.0 & 766.1 & 758.0 & 38,6 & 38,6 & 38,6 & 38,2 & 38,1 \\
\hline Slovakia & 6 & 8 & 4 & 4 & 3 & 398.5 & 378.1 & 426.7 & 449.0 & N.A & 5,3 & 5,3 & 5,3 & 5,3 & 5,3 \\
\hline Slovenia & 7 & 11 & 9 & 8 & 1 & 1198.4 & 1257.6 & 1194.1 & 1240.2 & N.A & 1,9 & 1,9 & 1,9 & 1,9 & 1,9 \\
\hline Romania & 48 & 46 & 38 & 24 & 23 & 195.2 & 180.4 & 221.4 & 243.8 & 251.2 & 22,4 & 22,4 & 22,4 & 22,3 & 22,2 \\
\hline Bulgaria & 4 & 7 & 7 & 4 & 2 & N.A & N.A & 192.3 & 202.0 & 207.2 & 8,2 & 8,1 & 7,9 & 7,8 & 7,8 \\
\hline Turkey & 56 & 50 & 55 & 44 & 21 & N.A & N.A & N.A & N.A & N.A & 66,2 & 67,4 & 68,5 & 69,6 & 70,7 \\
\hline
\end{tabular}

Source; World Bank (2004), World Development Indicators for inflation and total population. Eurostat for monthly wages.

* NACE Rev.1, Total industry, excluding construction.

with the findings of most studies on determinants of FDI, it is clear from Table 9 that the leading CEECs in attracting FDI (e.g. the Czech Republic, Hungary and Poland) are the ones with a large population. Table 9 also indicates that Romania and Turkey have not made use of their large population in attracting foreign capital so far.

Empirical studies examining motivations of foreign firms investing in Turkey find market-seeking factors to be the dominant incentive. From surveys of 93 foreign firms in Turkey, Erdilek (1982) and Demirbag et al. (1995) find out that meeting domestic demand are the key reasons for investing. In a more recent survey of 98 foreign firms Tatoglu and Glaister (2000), argue that the most important strategic motives for FDI in Turkey are to gain access to new markets and to enable faster market access and that market size and the growth rate of the economy to be key location factors influencing foreign investment in Turkey.

Recent levels of production cost are examined further in Table 10 by comparing the minimum wages in 2003 and 2004 as well as the minimum wages according to Purchasing Power Parity ${ }^{21}$ (P.P.P) in 2003. Similar to the monthly wages in Table 9, it appears that the levels of minimum wages and wages according to Purchasing Power Parity in Romania and Bulgaria are lower than the other and that the Czech Republic, Hungary and Poland have a rather equivalent minimum wage structure of around $€ 200$.

Table 10. Comparison of Turkey with Romania, Bulgaria and the 10 new members of the EU in terms of minimum wages

\begin{tabular}{lccc}
\hline & 2003 Minimum Wages & 2003 Minimum wages & \multicolumn{2}{c}{ 2004 Minimum Wages } \\
& $€$ & $€(P . P . P)^{*}$ & N.A. \\
\hline Cyprus & N.A. & N.A. & 212 \\
Czech R. & 197 & 405 & 159 \\
Estonia & 138 & 265 & 209 \\
Hungary & 191 & 363 & 122 \\
Latvia & 107 & 247 & 145 \\
Lithuania & 125 & 280 & 549 \\
Malta & 537 & 809 & 180 \\
Poland & 180 & 386 & 152 \\
Slovakia & 134 & 293 & 466 \\
Slovenia & 444 & 660 & 69 \\
Romania & 66 & 170 & 61 \\
Bulgaria & 57 & 195 & 245 \\
Turkey & 184 & 375 & \\
Source: & & & \\
\hline
\end{tabular}

Source: Eurostat. * Wages according to Purchasing Power Parity. 
Obviously not only the cost of production but also the quality of labour is an important factor for foreign investment. Loewendahl and Ertugal Loewendahl (2001) examined the quality of labour in 47 countries. They conclude that Turkey's ranking is above all countries in their sample and that only Hungary and Ireland are close to matching Turkey's labour quality.

\section{Causality relationships between FDI, exports and imports for Turkey, the Czech Republic, Hungary and Poland}

\subsection{Theoretical discussion on relation between FDI and trade}

In this section we focus on the causal relationship between FDI and exports, and FDI and imports, which could run in either direction. With regard to exports, initially, firms trade in the foreign market, and after learning more about the economic, social, political and ruling conditions of their trading partners they may establish a subsidiary in the host country (Liu et al., 2001) or they may embark on joint ventures with local enterprises. This implies FDI inflows, and, after some period, MNCs may start to export (UNCTAD, 1996; Rob and Vettas, 2003). The role of MNCs in expanding exports in 15 host countries derives from the additional capital, new technology and better management and marketing strategies that they can bring with them (UNCTAD, 2002). Thus, there may be a bi-directional causal link: exports stimulate FDI and FDI promotes exports.

Similarly, there are two possible bi-directional links between FDI and imports. First, if imports are evidence that a market exists for a commodity, FDI might be attracted to the host country to produce that product locally. In other words, a rise in imports in the host country justifies investment and production by MNCs; thus, imports stimulate FDI inflows. Second, as soon as MNCs establish in the host country, they import certain types of supplies (basic components and intermediate goods produced by the headquarters) to satisfy the quality standards required by the international market; therefore, FDI inflows increase the demand for imports.

\subsection{Methodology}

We use the Granger causality methodology to test for the relationship between FDI inflows and exports, and FDI inflows and imports ${ }^{22}$. In a bivariate framework, the variable $x$ is said to cause the variable $y$ in the Granger sense if the forecast for $y$ improves when lagged variables for $x$ are taken into account in the equation, ceteris paribus (Charemza and Deadman, 1997). In other words, the standard Granger causality procedure is based on past changes in one variable explaining actual changes in another variable. Testing causality, in the Granger sense, involves using an F-test (or Wald test). The appropriate formulation of a Granger-type test of causality (which must be applied to stationary series) is:

$$
\begin{aligned}
& \mathrm{X}_{\mathrm{t}}=\beta_{0}+\beta_{1} \mathrm{X}_{\mathrm{t}-1}+\ldots+\beta_{\mathrm{j}} \mathrm{X}_{\mathrm{t}-\mathrm{j}}+ \\
& \theta_{1} \text { FDI }_{\mathrm{t}-1}+\ldots+\theta_{\mathrm{j}} \text { FDI }_{\mathrm{t}-\mathrm{j}}+\mu_{t,}, \\
& \text { FDI }_{\mathrm{t}}=\delta_{0}+\delta_{1} \text { FDI }_{\mathrm{t}-1}+\ldots+\delta_{\mathrm{j}} \text { FDI }_{\mathrm{t}-\mathrm{j}}+ \\
& \gamma_{1} \mathrm{X}_{\mathrm{t}-1}+\ldots+\gamma_{\mathrm{j}} \mathrm{X}_{\mathrm{t}-\mathrm{j}}+v_{t}, \\
& \mathrm{M}_{\mathrm{t}}=\varphi_{0}+\varphi_{1} \mathrm{M}_{\mathrm{t}-1}+\ldots+\varphi_{\mathrm{j}} \mathrm{M}_{\mathrm{t}-\mathrm{j}}+ \\
& \alpha_{1} \text { FDI }_{\mathrm{t}-1}+\ldots+\alpha_{\mathrm{j}} \text { FDI }_{\mathrm{t}-\mathrm{j}}+\sigma_{t}, \\
& \text { FDI }_{\mathrm{t}}=\psi_{0}+\psi_{1} \text { FDI }_{\mathrm{t}-1}+\ldots+\psi_{\mathrm{j}} \text { FDI }_{\mathrm{t}-\mathrm{j}}+ \\
& \xi_{1} \mathrm{M}_{\mathrm{t}-1}+\ldots+\xi_{\mathrm{j}} \mathrm{M}_{\mathrm{t}-\mathrm{j}}+\tau_{t}, \\
& \mathrm{j}=1,2, \ldots, N,
\end{aligned}
$$

where $\mathrm{X}$ is exports, FDI is foreign direct investment inflows, $\mathrm{M}$ is imports; $\mu t, v t$, $\sigma t$, and $\tau t$ are error terms with zero mean. In equation (1), the null hypothesis ' $F D I$ does not Granger cause $X$ ' $\left(\theta_{1}=\ldots\right.$ $=\theta_{\mathrm{j}}=0$ ) is tested using a standard F-test (Wald test). It is rejected if the $\theta_{\mathrm{s}}$ are jointly significantly different from zero. Similarly, in equation (2) the null hypothesis ' $X$ does not Granger cause FDI' $\left(\gamma_{1}=\ldots=\right.$ $\left.\gamma_{j}=0\right)$ is rejected if the $\gamma_{s}$ are jointly significantly different from zero. The same procedure applies for equations (3) and (4).

Considering the ARDL model developed in 1997 an error correction model for each of the four equations is derived:

$\Delta \mathrm{y}_{\mathrm{t}}=\lambda_{0}+\sum_{i=1}^{r} \beta_{\mathrm{yi}} \Delta \mathrm{y}_{\mathrm{t}-\mathrm{i}}+\sum_{i=0}^{s} \beta_{\mathrm{xi}} \Delta \mathrm{x}_{\mathrm{t}-\mathrm{i}}+\pi \rho_{\mathrm{t}-1}+\varepsilon_{\mathrm{t}},(5)$

where $\rho_{t-1}$ is the lagged error correction term obtained from the residuals in each equation (equations 1 to 4) and $\varepsilon t$ is the random disturbance term. From equation (5) the null hypothesis that ' $x$ does not Granger cause $y$ ' would be rejected if the lagged coefficients of the $\beta x i$ 's are jointly significantly different from zero, using a standard F-test (Wald test).

In case of cointegration between $x$ and $y$, changes in one variable towards its long run equilibrium value may be a result of variations in the other variable. As well, the causality between $x$ and $y$ could be identified if the error term $\left(\rho_{t-1}\right)$ is statistically significant. 
Notice that the Granger test results only indicate that the changes in $x$ must come before the changes in $y$ (Murkherjee et al., 1998). A statistically significant coefficienc on $\rho_{t-1}(\pi)$ shows how the short run coefficients of the endogenous variable adjust towards the long run equilibrium in reaction to changes in the exogenous variables.

In order to obtain consistent results derived from the Granger causality procedure two steps are followed. The first step is to test the order of integration of the variables. The second step is to carry out the Granger causality tests.

\subsection{Empirical Analysis}

The tests are carried out on annual data. The data source is the UNCTAD World Investment Report
(2004) for FDI inflows and the United Nations COMTRADE Data for exports and imports. All variables are in real terms and are expressed in US dollars. Before we apply the Granger causality tests outlined in the previous section, it is necessary to determine the order of integration of the variables. The ADF test is used for this purpose.

Table 11 (part A) reports the ADF (one lag) test for the $\log$ levels of the variables and first differences under the assumption of a constant and (part B) under the assumption of a constant and deterministic time trend. The ADF test results for unit roots confirm that all variables are integrated of order one in levels but integrated of order zero in first differences at the 5 per cent level of significance. ${ }^{23}$

The next step is to test for the causal relationships between FDI inflows, exports and imports. Table 12

Table 11. Unit root tests for stationarity

\begin{tabular}{|c|c|c|c|c|}
\hline \multicolumn{5}{|c|}{ THE CZECH REPUBLIC } \\
\hline \multirow[b]{2}{*}{ Variables } & \multicolumn{2}{|c|}{$\begin{array}{c}\text { PART A } \\
\text { with Constant Only, } \\
\text { sample period 1992-2004 } \\
\end{array}$} & \multicolumn{2}{|c|}{$\begin{array}{c}\text { PART B } \\
\text { with Constant and Time Trend, } \\
\text { sample period 1970-2004 }\end{array}$} \\
\hline & Log Level $^{1}$ & Differences $^{1}$ & Log Level $^{2}$ & Differences $^{2}$ \\
\hline FDI & -0.46 & $-5.21^{*}$ & -0.67 & $-5.41^{*}$ \\
\hline $\mathbf{X}$ & -1.26 & $-6.05^{*}$ & -0.19 & $-6.59^{*}$ \\
\hline \multirow[t]{3}{*}{$\mathbf{M}$} & -1.59 & $-5.37^{*}$ & $-3.96^{*}$ & $-5.50^{*}$ \\
\hline & \multicolumn{3}{|c|}{ HUNGARY } & \\
\hline & \multicolumn{2}{|c|}{$\begin{array}{c}\text { PART A } \\
\text { with Constant Only, } \\
\text { sample period 1986-2004 }\end{array}$} & \multicolumn{2}{|c|}{$\begin{array}{c}\text { PART B } \\
\text { with Constant and Time Trend, } \\
\text { sample period 1992-2004 } \\
\end{array}$} \\
\hline Variables & Log Level $^{1}$ & Differences $^{1}$ & Log Level $^{2}$ & Differences $^{2}$ \\
\hline FDI & -0.13 & $-10.82^{*}$ & -1.08 & $-10.95^{*}$ \\
\hline $\mathbf{X}$ & -0.94 & $-6.65^{*}$ & -2.13 & $-6.79^{*}$ \\
\hline \multirow[t]{3}{*}{$\mathbf{M}$} & -0.76 & $-9.46^{*}$ & -0.63 & $-8.91^{*}$ \\
\hline & \multicolumn{3}{|c|}{ POLAND } & \\
\hline & \multicolumn{2}{|c|}{$\begin{array}{c}\text { PART A } \\
\text { with Constant Only, } \\
\text { sample period 1980-2004 }\end{array}$} & \multicolumn{2}{|c|}{$\begin{array}{c}\text { PART B } \\
\text { with Constant and Time Trend, } \\
\text { sample period 1986-2004 } \\
\end{array}$} \\
\hline Variables & Log Level $^{1}$ & Differences $^{1}$ & Log Level $^{2}$ & Differences $^{2}$ \\
\hline FDI & -1.16 & $-5.52^{*}$ & -0.67 & $-6.78^{*}$ \\
\hline $\mathbf{X}$ & -1.57 & $-12.76^{*}$ & $-3.42^{*}$ & $-12.19^{*}$ \\
\hline \multirow[t]{3}{*}{$\mathbf{M}$} & -0.29 & $-9.94^{*}$ & -0.73 & $-10.52^{*}$ \\
\hline & \multicolumn{3}{|c|}{ TURKEY } & \\
\hline & \multicolumn{2}{|c|}{$\begin{array}{c}\text { PART A } \\
\text { with Constant Only, } \\
\text { sample period } 1970-2004\end{array}$} & \multicolumn{2}{|c|}{$\begin{array}{c}\text { PART B } \\
\text { with Constant and Time Trend, } \\
\text { sample period 1980-2004 } \\
\end{array}$} \\
\hline Variables & Log Level $^{1}$ & Differences $^{1}$ & Log Level $^{2}$ & Differences $^{2}$ \\
\hline FDI & $-1,65$ & $-4,08^{*}$ & $-3,32$ & $-4,00^{*}$ \\
\hline $\mathbf{X}$ & $-0,69$ & $-13,33^{*}$ & $-3,77^{*}$ & $-14,72^{*}$ \\
\hline M & $-0,34$ & $-4,20 *$ & $-2,14$ & $-4,35^{*}$ \\
\hline
\end{tabular}

Notes: ${ }^{1}$ The critical value for rejection of hypothesis of a unit root is $-3.00 .{ }^{2}$ The critical value for rejection of hypothesis of a unit root is -3.60 . The asterisk $(*)$ denotes significance at the 5 per cent level. 
Table 12. Granger Causality Tests for FDI, Exports and Imports

\begin{tabular}{|c|c|c|c|}
\hline Null Hypothesis & F-Statistic & Probability & $\begin{array}{c}\text { Direction of } \\
\text { Causality }\end{array}$ \\
\hline \multicolumn{4}{|c|}{$\begin{array}{c}\text { CZECK REPUBLIC } \\
(1992-2004) \\
\end{array}$} \\
\hline $\begin{array}{l}\text { 1. FDI does not Granger Cause EX } \\
\text { EX does not Granger Cause FDI }\end{array}$ & $\begin{array}{l}0.91918 \\
0.61756 \\
\end{array}$ & $\begin{array}{l}0.44852^{*} \\
0.57032^{*}\end{array}$ & FDI $\leftrightarrow \mathrm{X}$ \\
\hline $\begin{array}{l}\text { 2. FDI does not Granger Cause IM } \\
\text { IM does not Granger Cause FDI }\end{array}$ & $\begin{array}{l}135.662 \\
0.26414\end{array}$ & $\begin{array}{l}0.32652^{*} \\
0.77635^{*}\end{array}$ & FDI $\leftrightarrow \mathrm{M}$ \\
\hline \multicolumn{4}{|c|}{$\begin{array}{l}\text { HUNGARY } \\
(1986-2004)\end{array}$} \\
\hline $\begin{array}{l}\text { 1. FDI does not Granger Cause EX } \\
\text { EX does not Granger Cause FDI } \\
\end{array}$ & $\begin{array}{l}0.19527 \\
0.96385\end{array}$ & $\begin{array}{l}0.82518^{*} \\
0.40908^{*}\end{array}$ & FDI $\leftrightarrow \mathrm{X}$ \\
\hline $\begin{array}{l}\text { 2. FDI does not Granger Cause IM } \\
\text { IM does not Granger Cause FDI }\end{array}$ & $\begin{array}{l}0.03034 \\
0.63681 \\
\end{array}$ & $\begin{array}{l}0.97019^{*} \\
0.54595^{*}\end{array}$ & FDI $\leftrightarrow \mathrm{M}$ \\
\hline \multicolumn{4}{|c|}{$\begin{array}{l}\text { POLAND } \\
(1980-2004)\end{array}$} \\
\hline $\begin{array}{l}\text { 1. FDI does not Granger Cause EX } \\
\text { EX does not Granger Cause FDI }\end{array}$ & $\begin{array}{l}128.114 \\
145.431\end{array}$ & $\begin{array}{c}0.00035 \\
0.02597^{* *}\end{array}$ & $\mathrm{X} \rightarrow \mathrm{FDI}$ \\
\hline $\begin{array}{l}\text { 2. FDI does not Granger Cause IM } \\
\text { IM does not Granger Cause FDI }\end{array}$ & $\begin{array}{l}283.084 \\
339.819\end{array}$ & $\begin{array}{l}0.08532^{*} \\
0.05597^{*}\end{array}$ & FDI $\leftrightarrow \mathrm{M}$ \\
\hline \multicolumn{4}{|c|}{$\begin{array}{l}\text { TURKEY } \\
(1970-2004) \\
\end{array}$} \\
\hline $\begin{array}{l}\text { 1. FDI does not Granger Cause EX } \\
\text { EX does not Granger Cause FDI }\end{array}$ & $\begin{array}{l}491.438 \\
117.274\end{array}$ & $\begin{array}{c}0.01482^{* *} \\
0.00020\end{array}$ & $\mathrm{FDI} \rightarrow \mathrm{X}$ \\
\hline $\begin{array}{l}\text { 2. FDI does not Granger Cause IM } \\
\text { IM does not Granger Cause FDI }\end{array}$ & $\begin{array}{l}215.434 \\
198.325\end{array}$ & $\begin{array}{c}0.13482^{*} \\
0.00431\end{array}$ & $\mathrm{FDI} \rightarrow \mathrm{M}$ \\
\hline
\end{tabular}

Note: The asterisk $(*)$ and double asterisk $(* *)$ denote significance at the 5 and 10 per cent level, respectively.

shows the results, which point to some patterns for the Granger causal links between FDI inflows, exports and imports in Turkey and the other three countries. We can draw the following conclusions from Table 12 .

a. Our results suggest a bi-directional Granger causality relationship between FDI and foreign trade (FDI $\leftrightarrow \mathrm{X}$ and FDI $\leftrightarrow \mathrm{M}$ ) in the Czech Republic and Hungary over the period 1992-2004 and 1986-2004, respectively ${ }^{24}$. This finding is consistent with fact that following the process of transition from socialism to capitalism and the integration into the world economy and the European Union in the early nineties, both foreign trade and capital flows have constantly increased in the Czech Republic and Hungary ${ }^{25}$.

As EBRD 2002 discuss, FDI in transition economies may facilitate growth, promote technical innovation, and accelerate enterprise restructuring also providing capital account relief. In addition, Mayhew (1998) argue prospective EU membership may be an important determinant of FDI for the CEECs. Some other factors such as, political stability (Jun and Singh, 1996) and the form of privatization, capital market development and the state of the legal framework (Brenton et al. (1999) and Meyer (1998) have also been considered as important determinants of FDI in transition economies.

b. It appears that the relationship between FDI and foreign trade in Poland is quite different than that of the Czech Republic and Hungary. Our results suggest a unidirectional Granger causality between FDI and exports running from exports to FDI (X $\rightarrow$ FDI) and a bi-directional Granger causality relationship between FDI and imports (FDI $\leftrightarrow \mathrm{M}$ ) in Poland over the period 1980-2004.

The most basic reason for this difference may be the different time periods we considered in our analysis due to data unavailability. The time episode for Poland (1980-2004) includes the period before transition process. However, there may be some other factors. As Dries and Swinnen (2004) argue, Poland is the largest of the transition countries and Poland is unique among the countries in that it had a mixed institutional structure, particularly in agriculture, under the Communist regime.

c. There is evidence of unidirectional Granger causality between exports and FDI in Turkey and the direction of causality runs from FDI to exports (FDI $\rightarrow \mathrm{X}$ ) suggesting that FDI inflows encourage exports. ${ }^{26}$ This result is supported by our previous descriptive analysis in 
Section 2, where we have shown that Turkey experienced a notable increase in exports after the implementation of the 1980 liberalization program (see Table 1$)^{27}$. However, FDI flows to Turkey have been still under $\$ 1$ billion over the two decades in post liberalization period and there was no evidence of any upward trend in FDI until the 2000s (see Figure 1).

Turkey's trade liberalization experience in the 1980s had a significant impact not only on the volume but also the commodity distribution of exports. The share of Turkey's exports of manufactured goods rose from 36 percent in 1980 to 93 percent in 2003 (see Table 1) reflecting the shift in commodity distribution of Turkey's exports. Blomström and Sjöholm (1999); Borensztein et al. (1998) and Aitken and Harrison (1997) offer empirical evidence on the importance of FDI flows for economic growth in developing countries by means of transferring high technology and knowledge spillovers. Therefore, it can be argued that there may be a relation between not only the volume but also the commodity variety of Turkey's exports and FDI.

The second set of results also shows unidirectional causality relationship between imports and FDI in Turkey. The direction of causality is from FDI to exports (FDI $\rightarrow$ M) suggesting that FDI inflows put upward pressure on Turkey's imports. This is not a surprising result as FDI increases demand for intermediate products and capital equipment grows because foreign companies require additional inputs for domestic and export products.

In sum, it seems FDI is linked with both exports and imports, therefore, international trade and trade balance of Turkey. The close relation between foreign investment and trade flows reflects opportunities to set up new development strategies for Turkey using FDI as a channel of technology transfer either through learning-by-exporting into industrial countries (Clerides et al., 1997) or through imports of high tech products and capital equipment (Feenstra et al., 1992).

\section{Conclusion}

The number of comparative studies on the structure of FDI in Turkey and the CEECs is scant. This paper is the first attempt to examine foreign investment in Turkey and the CEECs within a comparative framework. Our analysis on the causality between FDI and foreign trade is also the first attempt to study the existence of any possible link between foreign investment flows and trade in Turkey.

The observation that FDI flows to candidate CEECs doubled in the 1997-99 period lead us to conclude that, following the European Union's decision in December 2004 to start the negotiations with Turkey in October 2005, Turkey's European vocation is no longer in doubt and that FDI flows into Turkey will also grow exponentially in 2005 and thereafter. It is a convincing argument that the prospect of membership in the EU will be the key to sustained stability and welfare in Turkey as it had been in all existing and potential members of the EU.

In descriptive part of this paper we evaluate Turkey's competitive position in attracting FDI relative to its Central and Eastern European competitors in meeting the enabling economic and political determinants of FDI. We find that Turkey has not been able to compete successfully with the CEECs for FDI, despite its very strong underlying competitive position resulting from high labour productivity. We argue that Turkey's competitiveness was held back particularly by the price instability and that the low levels of privatization-related FDI was the major factor explaining Turkey's under-performance in attracting FDI relative to the CEECs taken as group. We conclude that these factors, together with institutional and political reasons, prevented the country to fully exploit its formidable potential in attracting foreign investment.

Following the descriptive part, we present an empirical causality analysis on the relation between FDI and trade in Turkey and the Czech Republic, Hungary and Poland using the Granger causality methodology. Our findings on the link between foreign investment and trade flows provide empirical evidence of unidirectional Granger causality between 'FDI and exports' as well as 'FDI and imports'. The direction of the causality is only from FDI to trade flows suggesting that Turkey's economic and political polities towards attracting more FDI to Turkey will unquestionably have a significant impact on the country's trade balance. Therefore, our study implies that there is a close relation and hence dependence between level of FDI and trade and development strategies of Turkey. As a result, the policy implication of our work is that the government should consider the fact that the macroeconomic policies headed for increasing the level of foreign investment in the country will also have some unavoidable effects on the balance of payments, the current account deficit and the overall international competitiveness of Turkey.

It seems that the relationship between FDI and foreign trade in Poland is quite different than that of the Czech Republic and Hungary. Our results suggest a bi-directional Granger causality relationship between FDI and foreign trade in the Czech Republic and Hungary, however, we find a unidirectional Granger 
causality between FDI and exports running from exports to FDI in Poland. Therefore, our work indicates that the dynamics behind FDI and foreign trade in the CEECs may differ crucially and that the relationship between foreign investment and trade flows should be examined further more using country-specific models.

Two interesting extensions come to mind. First, our study only provides a descriptive analysis of comparative attractiveness of Turkey and the CEECs. However, in order to achieve a deeper understanding of underlying factors of FDI, a country and industry specific analysis of determinants of FDI in Turkey and the CEECs is needed. Second, the Granger causality test we employed in this paper is very sensitive to the number of lags used in the analysis. Therefore, an investigation using different causality methods is essential to have more robust picture of the relation between FDI and trade in Turkey.

\section{Endnotes:}

1 OECD (2002)

2 See M. Dennis and L. Meredith (1986), L. Meredith (1991), J. H. Dunning (1998) and P. J. Buckley et al (2000) for the relationship between FDI and trade.

3 For more information and evaluation of the Post-liberalisation period, see, R. Anand et al. (1990); T. Aricanli and D. Rodrik (1990a, 1990b); I. Arslan and S. van Wijnbergen (1993); Y. Asikoglu and M. Uctum (1992); T. Baysan and C. Blitzer (1990, 1991); M. Celasun and D. Rodrik (1989); T. F. Nas and M. Odekon (Ed.) (1992); D. Rodrik (1990); F. Senses (1989, 1990); S. Wijnbergen et al. (1992); G. Kazgan, (1993).

4 R. Wade (1996) argues that Turkey was one of only 4 countries out of 24 OECD economies that on balance reduced obstacles to trade over the 1980s - the other 3 were Japan, Australia and New Zealand.

5 T. Aricanli and D. Rodrik (1990b) argue that the impressive export performance during the 1980s appears not to have produced an increase in private investment in tradables. They also stress the fact that exports in Turkey during the 1980s have relied on existing capacity from the 1970s.

6 In 2004 Turkey's exports and imports reached 63.1 and 97.5 Billion dollar respectively, resulting in about 34 Billion dollar trade deficit.

7 The new Law No. 4875 diminishes the prior 19 required steps to 3 steps and reducing turnaround from two and a half months to one day is enacted. Thus, the company registration procedures which previously were taking almost two and a half months and requiring excessive documentation and approvals from several authorities have been simplified and streamlined. Now the registration can be done in only one day and all that is required is to fill out a standard form at one point without applying to several different authorities for approvals.

8 According to World Investment Report 2002 of the UNCTAD, the main reasons for Turkey's low FDI performance can be listed as structural barriers, heavy bureaucratic requirements, macroeconomic instability, corruption, and political instability. The report also suggests that Turkey should be between Brazil and China, with $\$ 33.5$ billion and $\$ 105$ billion of annual FDI attraction, respectively.
9 Latest figures show that there are about 5.5 million Internet users in Turkey and penetration rate reached $7.3 \%$ as a result of $175 \%$ increase in Internet usage between 2000 and 2004. (Internet World Statistics)

10 According to US Department of State 2000, U.S.-origin capital has been invested in Turkey through third-country subsidiaries as a result of the absence of a bilateral tax treaty until 1998 with the US. By unofficial estimates the U.S. is actually the largest source of foreign investment in Turkey.

11 See E. Tatoglu and K. Glaister (1998a) and (1998b) for determinants of FDI in Turkey.

12 CEEC consists of Bulgaria, the Czech Republic, Hungary, Poland, Romania, Slovak Republic and Slovenia.

13 Turkey has been officially considered as a candidate country since the recommendation of the European Commission in 1999. The fulfillment of the so-called the Copenhagen criteria gave Turkey the chance of starting negotiations with the EU in 2005.

14 After starting negotiation talks with the EU in 1997, total FDI inflows to the Czech Republic and Poland reached to $€ 29$ billion and $€ 32$ billion, respectively within the five years between 1998 and 2002. (See Table 5.) See Raff (2004) for a discussion of link between preferential trade agreements and FDI.

15 See V. N. Balasubramanyam and N. Corless (2001) for a study of FDI in Turkey and Eastern Europe. See B. Yilmaz (2003) and B. Yilmaz and S. J. Ergun (2003) for an analysis of the international competitiveness of the Turkish economy and the specialization pattern of trade in comparison with Bulgaria, the Czech Republic, Hungary, Romania, Poland, and the EU15 as a whole.

16 The Czech Republic, Hungary, Poland are the largest CEECs and also the earliest members of the Central European Free Trade Area (CEFTA) which was established in 1992 by the former Czechoslovakia, Hungary and Poland.

17 In studies of the determinants of FDI, see for example, A. Bevan and S. Estrin (2004), GDP is used to represent the size of the source (host) country.

18 According to H.Loewendahl and E. Loewendahl (2001) Turkey's GNP and per capita income are underestimated as the private sector contributes to an "unregistered" economy, which increases GNP by up to $50 \%$.

19 In terms of price stability 2004 was a remarkable year for Turkey. According to Turkish Treasury the increase consumer price index in 2004 was only $9.32 \%$.

20 A. Bevan and S. Estrin (2004) and K. Carstensen and F. Toubal (2004) find that unit labor costs are negative and significant indicating that FDI flows are greater to locations with relatively lower unit labor costs, independent of distance or host country size. However, low wages do not necessarily reflect low production costs as labor productivity may be low. Therefore, the location decision of a multinational firm depends on the relative productivity-adjusted cost in the host country.

21 Purchasing power parity, PPP, is the belief that prices that are adjusted to the exchange rate are to be the same in all countries. The Swedish economist Gustav Cassel created the theory in 1917. The logic behind the theory is that prices are equalized though trade. The theory has been tested by many researchers and their results indicate a persistent departure from the Purchasing Power theory. See, for example, J.H. Bergstrand. Structural Determinants of Real Exchange Rates and National Price Levels, Some Empirical Evidence. American Economic Review. 1991: 325-334.

22 For an alternative causality test, known as Sims' test, see C.A. Sims. Money, Income, and Causality, American Economic Review, 62, September, 1972: 540-552.

23 For the critical values for ADF test see W. Fuller, Introduction to Statistical Time Series, New York: John Wiley, 1976.

24 Due to data unavailability, our analysis for the Czech Republic and Hungary covers these time periods. 
25 See F. Di Mauro (1999) and C. Buch et al. (2003) for further discussion.

26 M. Alguacil et al. (2002) find evidence of bi-directional Granger causality between FDI and trade (both exports and imports) for Mexico.

27 T. Aricanli and D. Rodrik (1990b) argue that Turkey's impressive export performance during the 1980 s appears have not produced an increase in private investment in tradables. They also stress the fact that exports during the 1980s have heavily relied on existing capacity from the 1970 s.

\section{References}

Aitken, B. J.; Harrison, A. E. (1997) "Do domestic firms benefit from direct foreign investments? Evidence from Venezuela", American Economic Review 89: 605-618.

Alessandrini, S. (ed.). (2009) The EU Foreign Direct Investments in Central and Eastern Europe. Milano.

Alguacil, M.; Cuadros, A. and Orts, V. (2002) "Foreign Direct Investment, Exports and Domestic Performance in Mexico: a Causality Analysis", Economic Letters 77: 371376.

Altomonte, C. (2000) "Economic determinants and institutional frameworks: FDI in economies in transition", Transnational Corporations 9 (August): 75-106.

Altomonte, C. and Guagliano, C. (2009) "Comparative study of FDI in Central and Eastern Europe and the Mediterranean", Economic Systems 27: 223-246.

Anand, R.; Chhibber, A.; Rocha R. and Wijnbergen, S. (1990) External Balance and Growth in Turkey: Can They Be Reconciled? in The Political Economy of Turkey: Debt, Adjustment and Sustainability, T. Aricanli and D. Rodrik (eds.), MacMillan, London.

Aricanli, T. and Rodrik, D. (eds.). (1990a) The Political Economy of Turkey: Debt Adjustment and Sustainability. MacMillan, London.

Aricanli, T. and Rodrik, D. (1990b) “An Overview of Turkey's Experience with Economic Liberalisation and Structural Adjustment", World Development 18 (10): 13431350.

Arslan, I. and Wijnbergen, S. (1993) "Export Incentives, Exchange Rate Policy and Export Growth in Turkey", The Review of Economics and Statistics 75(1): 128-133.

Asikoglu, Y. and Uctum, M. (1992) "A Critical Evaluation of Exchange Rate Policy in Turkey", World Development 20 (10): 1501-1514.

Baysan, T. and Blitzer, C. 1991 "Turkey", in Liberalising Foreign Trade: The New Zealand, Spain and Turkey: Vol. 6, D. Papageorgiou, M. Michaely and A.M. Choksi (eds.), A research Project of the World Bank, Cambridge: Basil Blacwell.

Baysan, T. and Blitzer, C. (1990) Turkey's Trade Liberalisation in the 1980s and Prospects for its Sustainability in The Political Economy of Turkey, Aricanli, T.; Rodrik, D. (ed), London: Macmillian Press Ltd.
Balasubramanyam, V. N. and Corless, N. (2001) "Foreign Direct Investment in Turkey and Eastern Europe", in Togan and Balasubramanyam (ed). Turkey and Central and Eastern European Countries in Transition, Palgrave.

Barell, R. and Holland, D. (2000) "Foreign direct investment in Central European manufacturing", in Weresa, Marzenna A. (ed.) Foreign Direct Investment in Transition Economies: The Polish Case, School of Slavonic and East European Studies. University College, London.

Bergstrand, J. H. (1991) "Structural Determinants of Real Exchange Rates and National Price Levels, Some Empirical Evidence", American Economic Review: 325-334.

Bevan, A. and Estrin, S. (2004) "The determinants of foreign direct investment into European transition economies", Journal of Comparative Economics 32: 775-787.

Blomström, M. and Sjöholm, F. (1999) "Technology transfer and spillovers: does local participation with multinationals matter?", European Economic Review 43: 915923.

Brenton, P.; DiMauro, F. and Lücke, M. (1999) "Economic integration and FDI: An empirical analysis of foreign investment in the EU and in Central and Eastern Europe", Empirica 26: 95-121.

Borensztein, E.; De Gregorio, J. and Lee, J. W. (1998) “How does foreign direct investment affect economic growth?", Journal International Economics 45: 115-135.

Buch, C.; Kokta, R. and Piazolo, D. (2003) "Does the East get what would otherwise flow to the South? FDI diversion in Europe", Journal of Comparative Economics 31: 94-109.

Buckley P. J.; Clegg, L. J.; Forsans, N. and Reilly, K. T. (2000) "The Evolution of FDI in the United States in the Context of Trade Liberalisation and Regionalisation", Journal of Business Research: 853-857.

Carstensen, K. and Toubal, F. (2004) "Foreign direct investment in Central and Eastern European countries: A dynamic panel analysis", Journal of Comparative Economics 32: 3-22.

Celasun, M. and Rodrik, D. (1989) Debt, Adjustment and Growth: Turkey, in Developing Country Debt and Economic Performance, Country Studies, Vol. 3, Sachs J. D. and Collins S. M. (ed.), Chicago: NBER and University of Chicago Press.

Charemza, W. W. and Deadman, D. F. (1997) New Directions in Econometric Practice. 2nd ed., England: Edward Elgar.

Clerides, S.; Lach, S. and Tybout, J. (1997) "Is learningby-exporting important? Micro-dynamic evidence from Colombia, Mexico and Morocco", Quarterly Journal of Economics 113: 903-947.

Demirbag, M.; Mirza, H. and Weir, D. T. H. (1995) "The Dynamics of Manufacturing Joint Ventures in Turkey and the Role of Industrial Groups", Management International Review 35 (Special Issue): 35-51. 
Dennis, M. and Meredith, L. (1986) "The Effect of U.S. and Canadian Wage and Productivity Differentials and FDI Status on the Canadian Propensity to Import U.S. Sourced Products", Weltwirtschaftliches Archives. University of Kiel, 122: 164-172.

Di Mauro, F. (1999) The effects of economic integration on FDI flows: an empirical analysis and comparison with trade, Document paper No. 134. Center for European Policy Studies, Brussels.

Dries, L. and Swinnen, J. F. M. (2004) "Foreign Direct Investment, Vertical Integration, and Local Suppliers: Evidence from the Polish Dairy Sector", World Development 32, (9): 1525-1544.

Dunning, J. H. (1998) "Globalization and the new geography of foreign direct investment", Oxford DevelopmentStudies 26 (1): 47-69.

EBRD. European Bank for Reconstruction and Development, 1994-2002 Transition Report, London. 2002.

Erdilek, A. (1982) Direct Foreign Investment in Turkish Manufacturing: An Analysis of Conflicting Objectives and Frustrated Expectations of a Host Country. Kieler Studien, No. 169, Tubingen: Paul Siebeck.

Estrin, S.; Hughes, K. and Todd, S. (1997) Foreign Direct Investment in Central and Eastern Europe. London: Cassel.

Eurostat web page, Population and Social Conditions.

http://epp.eurostat.cec.eu.int/portal/page?_pageid= 1090,1137397\&_dad=portal\&_schema=PORTAL

Feenstra, R.; Markusen, J. and Zeile, W. (1992) "Accounting for growth with new inputs: theory and evidence", American Economic Review 82: 415-421.

Foreign Investors Association (FIS),

http://www.yased.org.tr/page.asp?PageID=1103

Fuller, W. (1976) Introduction to Statistical Time Series. New York: John Wiley.

Granger, C. W. J. (1988) "Some Recent Development in a Concept of Causality", Journal of Econometrics 39: 199211.

Holland, D. and Pain, N. (1998) The diffusion of innovations in Central and Eastern Europe: A study of the determinants and impact of foreign direct investment. NIESR Discussion Paper No. 137, London.

Internet World Statistics, Usage and Population statistics http://www.internetworldstats.com/stats5.htm\#me

Yilmaz, B. (2003) Turkey's Competitiveness in the European Union: A Comparison with Five Candidate Countries - Bulgaria, The Czech Republic, Hungary, Poland, Romania - and the EU15, Ezoneplus Working Paper, No 12, February.

Yilmaz, B. and Ergun, S. J. (2003) The Foreign Trade Pattern and Foreign Trade Specialisation of Candidates of the European Union, Ezoneplus, Working Paper, No 19, September.
Jun, K. W. and Singh, H. (1996) "The determinants of foreign direct investment: new empirical evidence", Transatlantic Corporations 5: 67-106.

Kazgan, G. (1993) External Pressures and the New Policy Outlook, in Turkey and Europe. Balkir, C. and Williams, A. M. (ed.). London: Pinter Publishers Ltd.

Kornai, J. (1994) "Transformational recession: the main causes", Journal of Comparative Economics 19 (1): 39-63.

Kornai, J. (1995) "Transformational recession: General phenomenon examined through the example of Hungary's development", in Kornai, J. (ed.). Highway and Byways: Studies on Reform and Post-communist Transition. Cambridge: MIT Press.

Lavigne, M. (1999) The Economics of Transition: From Socialist Economy to Market Economy. 2nd Edition, Kent: Macmillan.

Liu, X.; Wang, C. and Wei, Y. (2001) "Causal Links between Foreign Direct Investment and Trade in China", China Economic Review 12: 190-202.

Loewendahl, H. and Loewendahl, E. (2001) Turkey's performance in attracting foreign direct investment Implications of EU enlargement. European Network of Economic Policy Research Institutes, Working Paper No. $8 /$ November.

Mayhew, A. (1998) Recreating Europe. Cambridge Univ. Press, Cambridge.

Meredith, L. (1991) "The U.S. Export and Foreign Direct Investment Linkage in Canadian Manufacturing Industries", Journal of Business Research: 73-88.

Meyer, K. E. (1998) Direct Investment in Economies in Transition. Aldershot: Edward Elgar.

Murkherjee, C. H. W. and Wuyts, M. (1998) Econometrics and Data Analysis for Developing Countries. London: Routledge.

Narula, R. and Wakelin, K. (1998) “Technological competitiveness, trade and foreign direct investment", Structural Change and Economic Dynamics 9: 373-387.

Nas, T. F. and Odekon, M. (ed.). (1992) Economics and Politics of Turkish Liberalization. London: Associated University Presses.

OECD. Foreign Direct Investment for Development; Maximizing Benefits, Minimizing Costs. Demetris, P.; Michaely, M. and Choksi, A. (ed). Cambridge: Basil Blackwell, 2002.

Raff, H. (2004) "Preferential trade agreements and tax competition for foreign direct investment", Journal of Public Economics 88: 2745- 2763.

Resmini, L. (2000) "The determinants of foreign direct investment in the CEECs: new evidence from sectoral patterns", Economies of Transition 8: 665-689.

Resmini, L. (2002) Interpreting inward FDI in the Mediterranean Basin and in Central and Eastern Europe: why so different? ISLA-Bocconi University Discussion Paper 4. 
Rob, R.; and Vettas, N. (2003) Foreign Direct Investment with Growing Demand. PIER Working Paper, 03-001.

Rodrik, D. (1990) "Some Policy Dilemmas in Turkish Macroeconomic Management", in Aricanli, T. and Rodrik, D. (ed.). The Political Economy of Turkey: Debt, Adjustment and Sustainability, London: MacMillan.

Roland, G. (2000) Transition and Economics: Politics, Markets and Firms. Cambridge: MIT Press.

Senses, F. (1989) "The Nature of Main Characteristics of Recent Turkish Manufactured Export Growth", Developing Economies, 27(1): 19-33.

Senses, F. (1990) An Assessment of the Pattern of Turkish Manufactured Export Growth in the1980s and Its Prospects, in the Political Economy of Turkey: Debt, Adjustment and Sustainability. Aricanli, T. and Rodrik, D. (ed.). London: Macmillan.

Sims, C. A. (1972) "Money, Income, and Causality", American Economic Review 62 (September): 540-552.

State Planning Organization of Turkey, Social Economic Indicators, 1950-2003.

http://ekutup.dpt.gov.tr/ekonomi/gosterge/tr/1950-03/3.zip

Tatoglu, E. and Glaister, K. (1998a) "Western MNCs' FDI in Turkey: an analysis of location specific factors", Management International Review 38(20): 133-59.

Tatoglu, E. and Glaister, K. (1998b) "Determinants of foreign direct investment in Turkey", Thunderbird International Business Review 40 (3): 279-314.

Tatoglu, E. and Glaister, K. (2000) Dimensions of Western Foreign Direct Investment in Turkey. London.

Treasury of Turkey, Foreign Investment Statistics, http://www.treasury.gov.tr/english/forinvest.htm

Togan, S. (1995) Trade Policy Review of the Republic of Turkey, in The World Economy Global Trade Policy. Arndt, S. and Milner, C. (ed.). Oxford: Blackwell Publishers Ltd.

Undersecretariat of Foreign Trade, Turkey, Foreign Trade Statistics,

http://www.foreigntrade.gov.tr/ead/english/Ekolar/STA.htm

UNCTAD (2001) Promoting linkages, World Investment report, United Nations Conference on Trade and Development and OECD. New York and Geneva.

United Nations Conference on Trade and Development (UNCTAD), (2004) World Investment Report 2004: The Shift Towards Services. Geneva.

United Nations Conference on Trade and Development (UNCTAD), (2003) World Investment Report 2003: FDI policies for Development, National and International Perspectives. Geneva.

United Nations Conference on Trade and Development (UNCTAD), (2002) World Investment Report 2002: Transnational Corporations and Export Competitiveness. Geneva.
United Nations Conference on Trade and Development (UNCTAD), (2004) World Investment Report.

http://www.unctad.org/en/docs/wir2004annexes_en.pdf

United Nations Statistics Division-Commodity Trade Statistics Database (COMTRADE), SITC. Rev-3.

http://unstats.un.org

US Department of State, (2000) FY2001 Country Commercial Guide: Turkey. Bureau of Economic and Business Affairs, July.

Utkulu, U. and Ozdemir, D. (2003) Does Trade Liberalization Cause a Long-run Economic Growth in Turkey?, EcoMod, Economic Modeling Annual Conference, July, Istanbul, 2003.

Wade, R. (1996) "Globalisation and its Limits: Reports of the Death of the National Economy are Greatly Exaggerated", in Berger, S. and Dore, R. (ed.). National Diversity and Global Competition. Cornell UP.

Wijnbergen, S.; Anand, R.; Chhibber, A. and Rocha, R. (1992) External Debt, Fiscal Policy and Sustainable Growth in Turkey. World Bank, Baltimore: The John Hopkins University Press.

World Bank, World Development Indicators, Online database. 2004.

http:/www.worldbank.org/data/onlinedatabases/onlinedatabases.html 